\title{
CULTURA PROLETÁRIA OU CULTURA UNIVERSAL? Sobre perspectivas culturais e educacionais nos primeiros anos da Revolução Russa (1917 - 1924)
}

\section{¿CULTURA PROLETARIA O CULTURA UNIVERSAL?}

Sobre perspectivas culturales y educativas en los primeros años de la Revolución Rusa (1917 - 1924)

\section{Cláudio Felix dos Santos}

Universidade Estadual do Sudoeste da Bahia. Pesquisa com apoio de bolsas IC (FAPESB e CNPQ)

\section{Resumo}

Cultura proletária ou cultura universal? Esse questionamento que delimita o núcleo da investigação apresentada neste texto analisa as divergências entre dirigentes revolucionários russos acerca dos rumos da cultura no embate político de transição ao socialismo. Este debate tem seu marco inicial no ano de 1908 e se acirra entre os anos de 1917 e 1924. As diferentes ideias colocavam de um lado Bolcheviques como Vladimir Lenin e Leon Trotski defendendo a necessidade da máxima apropriação da cultura universal na transição revolucionária ao socialismo; e, de outro, o movimento Proletkult (Cultura proletária) advogando a necessidade da construção de uma cultura produzida por meio dos saberes e experiências dos explorados, numa perspectiva de cultura do proletariado para o proletariado no processo revolucionário Russo. Nos embates prevaleceram as proposições dos Bolcheviques, em especial as preocupações de Lenin, que não era simpático à ideia de uma associação não ligada ao Partido Comunista influenciar ou dirigir a política cultural e educacional a ser implementada.

Palavras-chave: Revolução Russa. Cultura proletária. Cultura universal. 


\section{Resumen}

Cultura proletaria ou cultura universal? Este cuestionamiento que delimita el núcleo de la investigación presentada en este texto analiza las divergencias entre dirigentes revolucionarios rusos en lo que respecta a los rumbos de la cultura, en el debate político de transición al socialismo. Este debate tiene su marco inicial en el año 1908 y es mas evidente entre los años 1917 y 1924. Las diferentes ideas ponían en conflicto personalidades bolcheviques como Lenin y Trotski (defensores de la necesidad de la máxima apropiación de la cultura universal en la transición revolucionaria al socialismo) y, por otro lado, El movimiento Proletkult (Cultura proletaria) abogando la necesidad de la construcción de una cultura producida por medio de los saberes y experiencias de los explotados, desde una perspectiva de "cultura del proletariado para el proletariado" en el proceso revolucionario ruso. En los debates, prevalecieron las proposiciones de los bolcheviques, en especial las preocupaciones de Lenin, que no era simpático a la idea de una asociación no vinculada al Partido Comunista influenciar o dirigir la política cultural y educativa a ser implementada.

Palabras clave: Revolución Rusa. Cultura proletária. Cultura universal.

\section{Introdução}

Nos primeiros anos da revolução socialista, mais precisamente no período de comunismo de Guerrai, problemas inéditos estavam postos ao povo e aos dirigentes revolucionários. Neste período, 1918 a 1923, a questão da cultura e da educação se colocavam diante das dificuldades do enfrentamento à contrarrevolução e a modernização da base técnica, em especial a eletrificação da Rússia. Lenin (1968, p. 58), em discurso ao Congresso Nacional de Instrução Extra-Escolar, em maio de 1920, abordava que foi relativamente fácil derrubar o Czar, enfrentar a guerra, mas os obstáculos internos como a reeducação das massas e a luta contra a ignorância eram barreiras mais difíceis e demoradas a serem superadas.

Se se entende cultura como " o conjunto das práticas, das técnicas, dos símbolos e dos valores que se devem transmitir às novas gerações para garantir a reprodução de um estado de coexistência social" (BOSI,1992: 16), o esforço por se construir um novo modo de vida e uma nova visão de mundo demandaria uma mobilização profunda e ampla da sociedade russa em meio as dificuldades impostas pela realidade econômica no início do século XX naquele país. 
O esforço coletivo por construir uma nova forma de organização e produção da vida fez emergir debates e experiências em vários campos, dentre eles no plano da cultura e da educação. Neste sentido, uma questão fora levantada acerca da possibilidade de se construir uma cultura própria oriunda da classe trabalhadora. Essa proposição defendida pelo movimento Cultura Proletária (Proletkult) sofreu críticas de dirigentes Bolcheviques como Lenin e Trotski.

As divergências na condução das políticas de cultura e educação, ou mesmo da concepção dos agrupamentos políticos e culturais naquele primeiro momento da revolução oportunizou importantes reflexões e ações ao enfrentamento de problemas históricos de um país semifeudal com $79 \%$ da população vivendo no campo sob condições precárias de pobreza material, exploração do trabalho e de negação do acesso ao conhecimento. Dados de 1913 indicam que $80 \%$ das crianças estavam fora da escola, e que $73 \%$ da população era analfabeta (LÊNIN, 1977, p. 49-52 - vol I). Contraditoriamente, este país marcado pela negação da cultura letrada à grande maioria da população produzia uma literatura das mais avançadas do mundo. Em linhas gerais, este ambiente de radicais transformações deu base para uma longa discussão e muitas iniciativas acerca do que fazer no campo da produção cultural, instrucional e artística.

\section{O Proletkult e o debate sobre cultura e formação humana}

O movimento de Cultura Operária advogava a necessidade de construção de um novo sistema cultural tendo por base os saberes e experiências proletários. Isto envolveria o estabelecimento coletivo e consciente de uma nova moral, novas formas de organização política, novas expressões de arte que se contrapusessem as da elite czarista ou da cultura burguesa.

Desde o ano de 1905, o Proletkult já fazia do termo "cultura proletária" um objetivo central na luta contra a predominância do pensamento burguês na arte e na formação humana de um modo geral.

De acordo com Mally (1990), depois do fracasso da revolução de 1905 abriu-se uma crise no movimento socialista russo, em especial na ala bolchevique do Partido Socialdemocrata. Em 1907 o Governo Czarista e a polícia passaram a restringir as atividades políticas e a legalidade dos partidos e agrupamentos que se opunham ao regime. Os militantes 
do Partido Social-Democrata Russo, dentre eles Lenin, Trotski, Bogdanov, Lunatchárski tinham entendimentos diferentes em relação a tática de intervenção política naquele momento de repressão e dispersão das direções e das massas exploradas.

Lenin defendia a tática de articulação entre canais legais (participação em eleições, participação em sindicatos, inclusive nos de direção reacionária) combinados com atividades clandestinas para o desenvolvimento de formas de luta e organização das massas. Por sua vez, Bogdanov e o conjunto de militantes que o acompanhavam divergia desta tática e se autodenominavam "bolcheviques de esquerda" ou esquerdistas. Estes defendiam que os revolucionários não deveriam se iludir com o parlamento ou disputas pela direção de sindicatos reacionários. A forma mais auspiciosa de realizar a revolução seria partir para ações diretas, longe da institucionalidade.

Os esquerdistas que formaram a base de sustentação do Proletkult questionavam os métodos da organização Bolchevique e seu desdobramento nas ações políticas. Os mesmos propunham uma releitura da teoria marxista atribuindo à ideologia e a cultura um papel mais criativo e central no processo de lutas. Lunatchárski e Gorky, por exemplo, estavam convencidos de que o socialismo poderia transmitir a força de uma "religião humana" e inspirar as pessoas a olhar para além de si em busca de um bem maior para toda a humanidade. Na perspectiva de Bogdanov havia a necessidade de uma nova consciência no que dizia respeito à relação entre o indivíduo e a sociedade, o que requeria uma abordagem diferente para a ética, a ciência, os valores Humanos e a arte. (MALLY, 1990).

Em 1909, Bogdanov fora expulso das fileiras do Bolcheviques. Ele militava na ala Otzovista, agrupamento que "exigia que os deputados social-democratas fossem retirados (em Russo otzovat) da III Duma de Estado e que se pusesse fim ao trabalho nas organizações legais - sindicatos, cooperativas, etc.” (COUTINHO, 2014, p. 63). Essa postura não foi tolerada pela maioria dos Bolcheviques.

Nos anos de 1909 a 1911, durante o exílio na Itália, alguns intelectuais ligados aos Otzovistas fundaram duas escolas de exilados: uma em Capri e outra em Bolonha. Essas escolas contaram com professores do nível de Máximo Gorky, Lunatchárski, o historiador Mikharil Pokrovikii e o próprio Alexander Bogdanov. As aulas versavam sobre história do socialismo, literatura e artes visuais. Ainda eram oferecidos cursos de técnicas de agitação e redação jornalística (MALLY, 1990). 
Neste mesmo período Mach publicou o livro "Empiriomoism" (empiriocriticismo). O texto tece críticas ao materialismo histórico e formula as bases da "filosofia da experiência crítica" também denominada de Empiriocriticismo ou "Machismo"ii", tendência que influenciou Bogdanov.

A base para o surgimento da filosofia Empiriocriticista encontrava-se nas mudanças de "paradigmas" e métodos científicos das ciências naturais promovidas por grandes descobertas e invenções no século XIX, tais como o Raio X (1895); o fenômeno da radioatividade (1896); o elétron (1897); o rádio (1898). Essas descobertas provocaram questionamentos aos fundamentos teóricos das ciências da natureza, em especial da física. Um conjunto de conceitos foi refutado pelo fato de que muitos desses fundamentos se embasavam no materialismo mecanicista. Diante de tais transformações, filósofos e cientistas começaram a defender o desaparecimento da matéria, da inconsistência do materialismo, a negar o significado objetivo das teorias científicas, a ver o objeto das ciências apenas na descrição dos fenômenos (LENIN, 1983).

Para os discípulos de Mach, o que se costuma chamar de "matéria" ou "mundo exterior" seria somente um aspecto das sensações humanas. Segundo os Empiriocriticistas russos a realidade objetiva é inexistente. As coisas são o que se sente, não podendo transcender a isso (DELLA FONTE, 2010).

Em resposta a este texto, Lenin publicou em 1908 o livro "Materialismo e Empiriocriticismo" com o objetivo de criticar as distorções da filosofia empiriocriticista e suas influências no materialismo histórico. O título da introdução desta obra já explicitava o problema: "Em lugar de introdução - como certos "marxistas" refutavam o materialismo em 1908 e certos idealistas em 1710" (LENIN, 1983, p. 18). O autor pretendia revelar o equívoco e as ilusões dos "certos marxistas" que decepcionados ou encantados com os avanços da tecnologia ou da sociedade capitalista sepultavam as premissas materialistas históricodialéticas e retornavam a teorias idealistas. Segundo Vázquez (2007, cap. 4), Lenin observou que a filosofia empiriocriticista, como doutrina sobre o mundo, era idealista.

Neste mesmo ano de 1908, Alexander Bogdanov publica o livro "Krásnaia Zvezdá", traduzida com o título "Estrella Roja”, um romance de ficção científica. Este livro que trata de uma sociedade sem classes sociais no planeta Marte é um romance que não fala de transição socialista ou da revolução, mas da perspectiva de Bogdnanov acerca do comunismo, da etapa 

educacionais nos primeiros anos da Revolução Russa (1917 - 1924)

posterior ao socialismo. O personagem narra uma experiência de sociabilidade na qual as relações de exploração e dominação são superadas.

Neste livro Bogdanov aborda vários temas. A organização do trabalho nas fábricas onde os superiores não recebiam mais privilégios do que os operários. Discute a situação da mulher e a igualdade de direitos com os homens. Aborda a educação escolar, dentre outros temas. Ao tratar da arte, em um capítulo intitulado "O Museu de Arte", o narrador do romance indaga o porquê da existência de um lugar dedicado a exposição de obras de arte, visto que isso seria uma tradição capitalistas, aristocrática para expor o luxo e a riqueza para poucos. "Imaginei que em uma sociedade comunista a arte floresceria em todas as partes, lado a lado com a vida diária e embelezando-a" (BOGDANOV, 2010, p. 256). A este questionamento do protagonista, a resposta recebida é de que a arte estava em todo lugar. O museu de arte era o espaço dedicado a aprendizagem desta manifestação da cultura humana, ao estudo das grandes obras.

Por meio desta obra de ficção científica, Bogdanov desenvolvia sua crítica aos bolcheviques, em especial a Lenin, e no plano da política arregimentava muitos simpatizantes para o Proletkult.

Com a Revolução de Fevereiro de 1917 muitos exilados voltaram a Rússia e em outubro, com a tomada de poder pelos Bolcheviques, o Proletkult passou a reivindicar seu lugar no processo de construção socialista.

Segundo Mally (1990), o Proletkult estava interessado na criação de uma ética e moral proletária que perpassassem as relações familiares, educação das crianças e ciências da educação.

Importante atentar a relação de alguns membros do Proletkult com o governo revolucionário Russo. Refiro-me a Anatoli Lunatacharski, o primeiro comissário do povo para a instrução. Este intelectual foi um grande companheiro de Lenin. Eles se conheceram em 1904 e apesar de Lunatchárski nutrir simpatia e integrar o Proletkult, Lenin e os demais líderes bolcheviques o consideravam um camarada valoroso e fiel a causa revolucionária. Além disso, ele "surpreendida por seu talento. Escrevia versos, assimilava com facilidade as ideias filosóficas, fazia admiráveis conferências nas reuniões estudantis. Era um excelente orador, e nenhum tom faltava em sua palheta de escritos." (TROTSKI, 2007, p. 208). Todas essas referências fizeram de Lunatacharski um importante quadro na composição do governo, apesar de sua ligação com o Proletkult. 
No comando do povo para a Educação, Lunatacharski procurou mediar as tensões entre as diferentes correntes educacionais, Segundo Dore Soares (2000, p. 360) [...] ora colaborando com Bogdanov, ora atendendo às pressões pela profissionalização, ora atendendo às pressões de Lênin e Krupskaia, ora integrando os programas escolares a tendência 'maximalista' do papel do trabalho na escola.

Os membros do Proletkult defendiam que a classe trabalhadora era autônoma e deveria dar vazão a sua força criativa e expressão de suas ideias. Para tanto, o Proletkult buscava independência do partido comunista. (Mally, 1990) Esse fato ampliou ainda mais a desconfiança dos membros do Partido e do governo dos Soviets.

Com a revolução de outubro ampliaram-se grupos e organizações culturais, clubes independentes, cooperativas, grupos de komsomois (juventude). Havia uma grande vitalidade artístico-cultural que se expressava nos festivais que eram realizados em meio às lutas e guerra em defesa da revolução, tudo isso durante a penosa situação do país nos primeiros anos da revolução que buscava saídas por meio da política do comunismo de guerra (1918 a 1920).

Apesar dos obstáculos para a consolidação da revolução, vários movimentos artísticos se formaram neste período, em especial nos anos 1920, coincidindo com a implantação da Nova Política Econômica (NEP) ${ }^{\text {iii }}$. Como desdobramento desta política, o governo soviético fez altos investimentos em educação e estimulou a criação artística. Poderosos canais por meio dos quais se podia fazer avançar um novo ethos social e político foram experimentados.

$\mathrm{Na}$ onda do crescimento do debate e das ações sobre cultura, arte e educação revolucionária, o Proletkult deixou de ser uma organização local de artistas e intelectuais e se tornou uma ampla, importante e polêmica instituição nacional. Em termos numéricos, no ano de 1920 o Proletkult chegou a ter 80 mil membros e mais de quatrocentos mil simpatizantes. (MALLY, 1990). Este fato fez o movimento reivindicar o direito de participar na política soviética tal qual os sindicatos ou mesmo os Soviets. Tais pretensões recrudesceram as divergências com o núcleo dirigente do governo dos Soviets, em especial Lenin e Trotski que combateram as ideias e iniciativas do movimento. 
72 CULTURA PROLETÁRIA OU CULTURA UNIVERSAL? Sobre perspectivas culturais e educacionais nos primeiros anos da Revolução Russa (1917 - 1924)

\section{A concepção de cultura revolucionária e universal em Lenin e Trotski: implicações para a educação}

Duas eram as questões centrais da crítica de Lenin e Trotski ao Proletkult: uma em relação à concepção de cultura e outra de ordem político-revolucionária em meio ao crescimento do grupo liderado por Bogdanov.

De acordo com Trotski (2007), o socialismo era a transição para uma sociedade sem classes que colocaria, pela primeira vez na história, a possibilidade de uma cultura sem distinção de classe social. Uma cultura verdadeiramente humana. Portanto, era um equívoco dos maiores defender e lutar por uma cultura proletária. Segundo Trotski, o movimento fundado por Bogdanov, Lunatcharsk, Gorky baseava-se em mal-entendidos e ilusões.

O livro Literatura e Revolução, escrito por Leon Trotski nos verões de 1922 e 1923 é a principal referência do enfrentamento ao Proletkult naquele momento histórico, juntamente com os discursos de Lenin em vários eventos ocorridos na Rússia entre 1920 a 1922. Esta obra é um marco no debate para "a compreensão do conflito e da mudança cultural na época da Revolução Russa - e também para orientar as formas como pensamos a relação entre as transformações políticas e culturais em qualquer momento histórico, inclusive o nosso" (KEACH, 2007, p. 9). Este texto foi escrito reunindo um conjunto de artigos que Trotski elaborou em meio às pressões dos países centrais no intuito de isolar a revolução no âmbito internacional e, por outro lado, no combate ao avanço de Stalin, em aliança com Zinoviev e Kamenev, quando estes tinham por objetivo de enfraquecer a influência de Trotski no partido e no Governo ${ }^{\text {iv }}$.

Não se pode entender o debate de Lenin/Trotski em contraposição ao Proletkult como uma discussão de concepções teóricas diletantes sem rebatimentos na prática revolucionária ou limitada ao problema da cultura e da arte isolada das questões econômicas e políticas do momento por eles vivenciado. Tanto em um como em outro dirigente, o problema da cultura e arte, assim como da instrução e educação configuravam-se como de extrema importância ao processo revolucionário.

A apropriação da cultura pelo proletariado, no entendimento de Trotski, guarda uma íntima aproximação com a sua teoria da Revolução Permanente. Esta teoria se apoia na concepção de Marx, segundo a qual não se pode transigir com nenhuma forma de dominação de classe, tampouco ter como ponto de chegada a revolução democrático-burguesa para a posteriori, o proletariado realizar a tomada de poder numa perspectiva socialista. A revolução 
permanente busca articular os avanços que a revolução burguesa proporcionou ao desenvolvimento das forças produtivas às medidas socialistas, sem negligenciar a guerra contra a reação exterior de destruição das conquistas revolucionárias. Assim, cada etapa contém em germe a etapa anterior até a definitiva supressão da propriedade privada e das classes sociais (TROTSKI, 2007a,).

Nas análises de Trotski (1967) sobre a Revolução Russa, o caráter burguês da revolução - ou seja as tarefas democráticas - teria no próprio proletariado russo o seu núcleo de comando. De acordo com Bezerra (2016, p.3), “A coincidência parcial dos objetivos entre burguesia, proletariado urbano e campesinato não significava necessariamente a cessão por parte destes últimos do poder resultante da primeira revolução”. Desdobrava-se, na verdade, uma luta entre as classes cujo desenvolvimento não estava dado por nenhum dogma. Mas sim na capacidade de cada classe responder ao processo revolucionário conforme sua força e organização.

É sob a lógica do desenvolvimento do capitalismo em sua fase imperialista, analisado primeiramente por Lenin em seu clássico “imperialismo a fase superior do capitalismo", que se desenhou uma perspectiva internacional de divisão do globo entre os capitalismos dominantes sobre os periféricos. No caso Russo, Trotski buscou explicar a dinâmica econômica daquele país por meio do conceito de desenvolvimento combinado. Este diz respeito a dinâmica econômica que inter-relaciona arcaicas formas de produção e relações sociais de produção com formas avançadas de geração de riqueza. Quanto a isso Trotski (1967, p. 29) formulava:

\footnotetext{
A indústria Russa, quanto à técnica e sua estrutura capitalista, encontrava-se no mesmo nível dos países adiantados e, mesmo sob alguns aspectos, os ultrapassava. Em 1914 as pequenas indústrias com menos de 100 operários representavam, nos EUA, 35\% do efetivo total dos operários industriais, ao passo que a Rússia a proporção era de 17,8\%.” (...) Este fato apresentado pela primeira vez em 1908, dificilmente poderia ser inserido na representação banal que nos dão de uma economia atrasada na Rússia. Entretanto, não nega o caráter retardatário do país, oferecendo apenas um complemento dialético.
}

Deste modo, o velho esquema mecanicista de revolução em duas etapas, sendo a primeira comandada pela burguesia para realizar as reformas econômicas e democráticas para, 

educacionais nos primeiros anos da Revolução Russa (1917 - 1924)

posteriormente, o proletariado fazer seu levante e tomar o poder, à revelia das análises das condições concretas contemporâneas, foi rechaçada por Trotski. Segundo Bezerra (2016, p. 4)

A teoria da revolução permanente partia de uma percepção oposta, segundo a qual não haveria interrupção entre a luta nacional e democrática e as tarefas socialistas, o que demandava uma ultrapassagem da concepção de dois programas, um mínimo e um máximo, que caracterizava o movimento operário na época pré-imperialista, em favor de um sistema de reivindicações transitórias que, partindo das tarefas imediatas, as ligasse às tarefas históricas da classe operária.

A revolução permanente diz respeito à articulação entre revolução nacional e democrática e a revolução socialista. Para Trotski (2007), a criação artificial e imediata de uma economia, de uma cultura, de uma educação e escolarização puramente socialista, nos primórdios da revolução, era de uma ingenuidade e idealismo sem tamanho. Portanto, necessário se fazia a realização de tarefas sobre a base do acúmulo da cultura (ciência, filosofia, arte) que a humanidade conseguiu alcançar por meio do desenvolvimento do sistema da propriedade privada dos grandes meios de produção. Empreendimentos promovidos pela revolução burguesa como o fim do analfabetismo e a instrução do povo configurava-se, na Rússia, como ações que caminhavam paralelamente à dinâmica revolucionária no esforço por ultrapassar os limites da revolução burguesa.

Por este raciocínio, sendo coerente com a teoria da revolução permanente, Leon Trotski se colocava contrário àquelas teorias ou proposições que defendiam transformações mecânicas e imediatas tomando a revolução como panaceia, sem que se considerasse um certo lapso de tempo para se construir respostas às demandas surgidas destes processos, dentre eles a questão da cultura, da arte e da educação. Como afirma Trotski, ilustrando poeticamente a necessidade da paciência histórica em relação ao desenvolvimento da cultura: “O rouxinol da poesia - como a ave do saber, a coruja - só é ouvido depois que o sol se põe. O dia é o tempo da ação, mas no crepúsculo o sentimento e a razão fazem o balanço do que se realizou." (Idem, p. 39). Esta formulação é uma crítica, sobretudo ao Proletkult, àqueles que julgavam necessária e possível a construção de uma cultura proletária saltando sobre as condições objetivas, em grande parte desconsiderando que a cultura se nutre da força da economia.

É preciso, porém, mais que o estritamente necessário à vida para que a cultura se desenvolva e aprimore. (...) O proletariado será capaz de preparar a formação de uma cultura e de uma literatura novas, isto é, socialistas, não 
por métodos de laboratório, à base da pobreza, necessidade, da ignorância de hoje, mas a partir de meios sociais, econômicos e culturais consideráveis. A arte necessita de bem-estar e abundância. Os fornos ainda devem esquentar, as rodas devem girar mais rapidamente, as lançadeiras devem correr mais depressa, as escolas devem funcionar melhor" (TROTSKI, 2007, p. 34).

Portanto, sem o fortalecimento da produção material da vida e, ao mesmo tempo, a apropriação dos bens não-materiais já existentes, a cultura e a arte socialistas seria apenas um embuste, ou mesmo uma "bajulação" ao proletariado limitando as possibilidades de máximo desenvolvimento das potencialidades criativas de todos e de cada um.

Leon Trotski entendia que cada classe dominante para criar a sua cultura e, por consequência, a sua arte e formas mais desenvolvidas de educação, precisava de tempo para sua elaboração. Para comprovar tal tese, ele analisa a emergência e consolidação do Renascimento cultural no século XV e da revolução francesa no século XVIII como o desenvolvimento de um longo processo de consolidação de uma cultura burguesa que expressava a sua força econômica e política. Segundo ele,

O renascimento, em todo caso, não começou antes que a nova classe social, já culturalmente saciada, se sentisse muito forte para sair do jugo do arco gótico, considerar o gótico e tudo o que o precedera como simples material à sua disposição e submeter os elementos do passado a seus fins arquitetônicos" (TROTSKI, 2007, p. 151).

Por sua vez, a revolução francesa consolidou a burguesia enquanto classe dominante mundial. Este processo fez com que o regime capitalista se firmasse em termos materiais e culturais produzindo um entendimento dominante de que o sistema de propriedade privada dos grandes meios de produção é algo natural e eterno. Em outras palavras, conseguiu produzir uma visão de mundo burguesa. Portanto, a criação de uma cultura burguesa levou pelo menos 300 anos e se prolongou até o momento em que uma experiência de transformação radical e de conjunto do modo de organizar a produção material e espiritual da

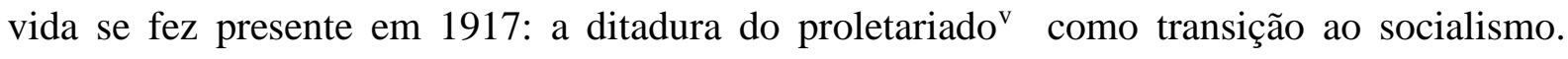
Trotski se preocupava com o tempo necessário e possível para a produção da cultura sob outras bases materiais porque "a cultura representa a soma orgânica de conhecimentos e informações que caracteriza toda a sociedade ou ao menos a sua classe dirigente. Ela abarca e penetra todos os domínios da criação humana e unifica-os num sistema. As realizações individuais levantam-se acima desse nível.” (Idem, p. 159). Todavia, a revolução cumpria o 
76 CULTURA PROLETÁria OU CULTURA UNIVERSAL? Sobre perspectivas culturais e educacionais nos primeiros anos da Revolução Russa (1917 - 1924)

papel de acelerar este processo, objetivando o fim da propriedade privada e das classes sociais. Ele ilustra, se bem que de modo esquemático/especulativo, a relação modo de produção e desenvolvimento da cultura do seguinte modo:

\begin{abstract}
As etapas fundamentais do desenvolvimento da humanidade - imaginamos irão assim se dividir: a pré-história do homem primitivo; a história da antiguidade, cujo desenvolvimento se apoiou na escravidão; a idade média baseada na servidão; o capitalismo, com a exploração assalariada; e enfim a sociedade socialista, com a transição sem dor - esperamos - para o comunismo, no qual toda forma de poder desaparecerá. Em todo o caso, os 20, 30 ou 50 anos que a revolução proletária mundial levará entrarão na história como a transição a mais penosa de um para outro sistema, e de modo algum como a época da cultura proletária" (TROTSKI, 2007, p. 153 - grifos nossos).
\end{abstract}

Cabe aqui uma indagação: As críticas e preocupações deste revolucionário significava a total negação da cultura proletária, sua subestimação ou desmerecimento? A resposta a essa indagação é negativa. Para ele uma coisa é imprimir uma marca proletária à cultura, à arte e à educação. Outra coisa é falar em cultura proletária.

No que diz respeito à arte socialista, esta deveria caminhar para formas cada vez mais profundas e complexas de expressão estética de uma verdadeira cultura socialista ainda em construção. O período da transição, no qual o que está velho ainda não morreu e o novo ainda está em gestação, ocorrerá inúmeras contradições, erros e acertos. Trotski observara que por mais talentosos e esforçados que fossem os poetas operários, seus textos ainda não expressavam uma literatura socialista, mas sim preocupações cotidianas e do interesse das massas trabalhadoras. Lançando mão de uma reflexão de um crítico literário de nome Dubovskoi, ele afirmou: "Pode-se dizer com muita razão que os Shakespeare e os Goeth proletários hoje correm descalços para alguma escola primária” (Idem, p. 160). Portanto era necessário, segundo o autor, produzir uma arte para além do imediato e do cotidiano. Uma arte que explorasse as preocupações, experiências, percepções do proletariado, mas que seja bem-feita porque

arte mal feita não é arte e, em consequência, os trabalhadores não precisam dela. O conformista da arte mal feita guarda no fundo boa parte do desprezo pelas massas e se torna muito importante para certos tipos de politiqueiros, que nutrem desconfiança orgânica na força da classe operária, mas a elogiam quando tudo vai bem (Idem, p. 162). 
A preocupação de Trotski em relação à produção artística e ao desenvolvimento da cultura e da educação por parte do proletariado russo coincidia com o entendimento de Vladimir Lenin sobre a questão.

Em relação ao Proletkult, Lenin entendia que tal movimento poderia se tornar um fator de desagregação política e ação contrarrevolucionária ${ }^{\mathrm{vi}}$. Em vários de seus discursos, em especial nos anos de 1919 e 1920, reiteradamente tecia duras críticas às teses que defendiam a necessidade de criação de uma cultura proletária.

$\mathrm{Na}$ saudação ao I Congresso Nacional de Instrução extraescolar realizado em 06 de maio de 1919, Lenin ao abordar os velhos e novos obstáculos para a formação humana do povo russo lembrou dos obstáculos externos, como a guerra. Contudo, enfatizou questões internas como os mais difíceis obstáculos neste terreno, a saber: a reeducação das massas, a organização popular e a instrução, a difusão do conhecimento, a luta contra a ignorância, a selvageria e o embrutecimento da classe trabalhadora no campo e na cidade. Para superar tais obstáculos, anunciava a necessidade, em primeiro lugar, de enfrentar a abundância de pessoas procedentes das camadas intelectuais burguesas que viam nos estabelecimentos de ensino e de formação extraescolar de camponeses e proletários “a arena mais propícia para suas invenções pessoais na esfera da filosofia ou da cultura, e apresentavam com frequência as mais estúpidas ostentações como algo novo e que, por arte puramente proletária e cultura puramente proletária, faziam passar algo sobrenatural e absurdo" (LENIN, 1968, p. 59).

Para este dirigente, se fazia necessário insistir na apropriação da cultura produzida sobre as bases do próprio capitalismo. Em muitos discursos sobre o tema da cultura, da educação e da instrução chamava a atenção para sua relação com a produção material e desenvolvimento técnico possibilitado pelo modo de produção capitalista. Em discurso proferido em 25 de fevereiro de 1920, Lenin (1968, p. 90 a 93) destacou a necessidade de alterar as bases da educação escolar e extraescolar articulando-as com a nova e mais avançada base técnica e econômica: a eletrificação. Esta era uma preocupação reiteradamente anunciada por este revolucionário, sobretudo para impulsionar a produção industrial e agrícola na União Soviética. Neste mesmo evento Lenin desenvolveu uma crítica aos velhos métodos de educação que subestimava a capacidade do campesinato e do proletariado por meio da falácia da criação de uma cultura proletária, que ele considerava "um entulho tão semelhante às enfermidades infantis" (Idem, p. 92). 
No discurso intitulado "tarefas das juventudes comunistas", proferido no III Congresso da União das Juventudes Comunistas da Rússia, em 02 de outubro de 1920 Vladimir Lenin falava a centenas de jovens sobre sua principal tarefa: aprender! Aprender sobretudo o comunismo. Todavia, ele afirmava que aprender o comunismo não diz respeito a ter acesso e repetir o que está posto nos manuais, folhetos e obras comunistas sob o risco de se formarem escolásticos ou fanfarrões que ao invés de contribuir com as lutas pela emancipação humana, as distorceriam.

De fato, admitia o dirigente, a separação entre o livro e a vida prática, entre teoria e prática como legado do capitalismo precisaria ser superado pela nova escola socialista. Contudo, "não se pode ser comunista sem ter assimilado o tesouro dos conhecimentos acumulados pela humanidade" (Idem, p. 98).

Reforçando sua argumentação, Lenin enfatizava que a defesa intransigente da apropriação do conhecimento científico, filosófico e artístico produzido pela humanidade, ou seja, o tesouro dos conhecimentos acumulados, foram as bases sobre as quais Marx e Engels chegaram à compreensão do desenvolvimento do capitalismo baseando-se no estudo mais detalhado e profundo da sociedade capitalista por meio da assimilação do que a ciência havia descoberto até então. Portanto, a escola moderna, no interior da sociedade socialista em construção, precisava garantir a aprendizagem dos conhecimentos modernos "sabendo transformar o comunismo, em lugar de fórmulas feitas, sentenças, receitas e programas aprendidos de memória, em algo vivo que coordene vossa atividade imediata, sabendo converter o comunismo em guia de vosso trabalho prático" (idem, p. 102). Portanto, era preciso extrair da velha escola o seu melhor, apropriar-se ao máximo da ciência enriquecendo a memória das jovens gerações a fim de se construir o trabalho comum (o comunismo).

Neste sentido, Lenin avançava em sua crítica ao proletkult, pois entendia que suas proposições eram diametralmente opostas as necessidades reais dos trabalhadores Russos. Afirmava ele:

É preciso ter em conta isso quando falamos, por exemplo, da cultura proletária. Sem compreender com clareza que só se pode criar esta cultura proletária conhecendo com precisão a cultura criada pela humanidade em todo o seu desenvolvimento e transformando-a. Sem compreender isso não poderemos cumprir esta tarefa. A cultura proletária não surge de fonte desconhecida, não é uma invenção dos que se proclamam especialistas em cultura proletária (LENIN, 1968, p. 112 -113). 
Seis dias após pronunciar este discurso aos jovens, Lenin, no dia 08 de outubro de 1920, durante o congresso do Proletkult, elaborou um projeto de resolução com 5 pontos com a finalidade de limitar as atividades daquele movimento político-cultural.

No primeiro ponto ele anuncia o objetivo central da instrução e da cultura no processo revolucionário. De acordo com sua formulação, toda a ação neste campo deve estar voltada para a derrubada da burguesia, supressão das classes e abolição de toda exploração do homem pelo homem.

Desta afirmação decorre a segunda argumentação de seu projeto de resolução sobre o Proletkult. Ali ele anuncia que "o proletariado deve tomar a parte mais ativa e principal em todos os assuntos relacionados com a instrução pública, personificado tanto por sua vanguarda, o Partido Comunista, como, em geral, por toda a massa de organizações proletárias de toda espécie" (Idem, p. 112).

$\mathrm{Na}$ terceira argumentação Lenin faz a defesa incisiva e intransigente do marxismo, reiterando ser esta concepção que exprime de modo correto os interesses, o ponto de vista e a cultura do proletariado revolucionário. Com esta afirmação ele se contrapõe veemente as ideias de Bogdanov e do empirocriticismo de Mach (tratados no início deste artigo).

A quarta consideração diz respeito a necessidade da apreensão da cultura universal como condição de possibilidade para uma cultura revolucionária no caminho do comunismo. “O Marxismo conquistou sua significação histórica universal como ideologia do proletariado revolucionário porque não rechaçou de modo algum as valiosas conquistas da época da burguesa (...) Só pode ser considerado desenvolvimento da cultura verdadeiramente proletária o trabalho ulterior sobre essa base e nessa mesma direção" (LENIN, 1968, p. 113).

Por fim, a quinta consideração é incisiva em relação às atividades do Proletkult:

Sustentando com firmeza este ponto de vista de princípio, o Proletkult de toda a Rússia rechaça com maior energia, como inexata teoricamente e prejudicial na prática, toda tentativa de inventar uma cultura especial própria, de fechar-se em suas próprias organizações isoladas, de delimitar as esferas da ação do Comissariado do Povo para a Instrução e do Proletkult, ou de implantar a "autonomia" do Proletkult dentro das instituições do Comissariado do Povo para a instrução etc. Ao contrário, o Congresso impõe a todas as organizações do Proletkult a obrigação irrecusável de considerarem-se inteiramente órgãos auxiliares da rede de instituições do Comissariado do Povo para a Instrução e cumprir suas tarefas, como parte das tarefas da ditadura do proletariado, sob a direção geral do Poder Soviético (especialmente do Comissariado do Povo para a Instrução) e do Partido Comunista da Rússia (LENIN, 1968, p.112). 
Por meio desta resolução o Proletkult teve suas pretensões de ampliar sua influência no governo dos Soviets frustradas, pois suas atividades foram suspensas. Em todos os seus discursos e ações, Lenin não titubeou em criticar teoricamente e usar sua força e influência para limitar as reivindicações de autonomia pleiteada pelo Proletkult, sempre com a argumentação da necessidade da prioridade da apropriação das formas e conteúdos científicos, filosóficos e artísticos por parte dos trabalhadores ${ }^{\mathrm{vii}}$.

\section{Conclusão}

O problema da cultura, da arte e da instrução foram bastante destacados neste primeiro período da revolução. Como observou Trotski (2007), o longo período de consolidação de uma cultura burguesa que se universalizou demandou tempo e trabalho daquela classe até sua consolidação enquanto tal. Na Revolução Bolchevique não seria diferente. Contudo, os objetivos e meios para a construção de uma nova visão de mundo, de educação e construção de uma cultura verdadeiramente humana, não-classista, em meio ao choque radical com tudo o que era tomado como verdade até então, estariam assentados em outros parâmetros, em especial no fim da propriedade privada dos grandes meios de produção.

De acordo com Mally (1990), os confrontos entre o Proletkult e o Partido Comunista tiveram um destaque na historiografia, tanto no Ocidente, quanto na antiga União Soviética. Como se procurou demonstrar, o debate sobre este tema emerge a partir de 1908 e se intensifica após a revolução de outubro de 1917. No período aqui analisado, este foi um debate rico e instigante com formulações explícitas tendo por um lado a defesa de elaboração de uma cultura proletária a partir dos saberes e experiências das massas e de outro a construção de uma cultura sobre as bases da máxima apropriação dos conhecimentos produzidos pelo conjunto da humanidade, mas apropriado privadamente por pequenas parcelas da sociedade.

Infiro que nestes embates se encontram as origens das discussões que se estende até os dias atuais acerca do lugar e de como tratar a relação entre cultura popular e erudita, o singular e o universal em formulações e experiências das organizações de esquerda e no debate acadêmico contemporâneo presente em teóricos e teorias que se reivindicam do campo crítico. $^{\text {viii }}$ 
As divergências que se colocaram no início do século XX acerca do difícil e complexo processo de construção de um novo modo de produção da vida e, por consequência, de uma nova visão de mundo, se fizeram presentes como desafios postos a partir da Revolução Russa de 1917.

O problema cultural - sua produção e apropriação - puseram duas perspectivas em conflito, todavia com objetivos comuns: o sucesso da revolução. Apesar disso, em termos de correlação de forças, prevaleceram as proposições dos Bolcheviques, em especial as preocupações de Lenin que não era simpático à ideia de uma associação não ligada ao Partido Comunista influenciar ou dirigir a política cultural a ser implementada.

Os 100 anos da Revolução Russa, um marco na luta de classes e das possibilidades de vitória dos trabalhadores, brindou a humanidade com ricas elaborações em várias dimensões. Os debates sobre cultura foi uma delas e teve nas divergências entre Proletkult e membros destacados do Partido Bolchevique uma referência para aquele período histórico, bem como elementos que auxiliam discussões neste campo nas lutas da classe trabalhadora no século XXI.

\section{Referências}

BANDEIRA, A. M. Prefácio. In TROTSKI, L. Literatura e Revolução. Rio de Janeiro: Zahar - Jorge Zahar Editor, 2007.

BEZERRA, J. E B. A questão da literatura e da arte na Revolução Russa. 2016. Disponível em http://otrabalho.org.br/a-questao-da-literatura-e-da-arte-na-revolucao.

BOGDANOV, A. Estrella Roja. Editor digital: SoporAeternus ePub base r1.2, 2015. Disponível http://assets.espapdf.com/b/Alexander\%20Bogdanov/Estrella\%20roja\%20(1974)/Estrella\%20 roja\%20-\%20Alexander\%20Bogdanov.pdf

COUTINHO, R. Notas Editoriais. In LENIN, V. I. O esquerdismo: doença infantil do comunismo. São Paulo: Expressão Popular, 2014.

DELLA FONTE, S. S. Considerações sobre o ceticismo contemporâneo a partir da ontologia e da gnosiolosia marxista. In DUARTE, N. DELLA FONTE, S. S. Arte, conhecimento e paixão na formação humana: sete ensaios de pedagogia histórico-crítica. Campinas: Autores Associados, 2010.

DORE SOARES, Rosemary. A concepção gramsciana do Estado e o debate sobre a escola. Ijuí: Editora UNIJUÍ, 2000. 
ILYENKOV, E. V. Leninist Dialectics and the Metaphisics of positivism: reflections on V.I LENIN'a book, "materialism an Empirio-Criticism". Londres, Inglaterra: New Park Publications, 1982.

KEACH, W. Apresentação. In TROTSKI, L. Literatura e Revolução. Rio de Janeiro: Zahar Jorge Zahar Editor, 2007.

LENIN, V. I. Marxismo e Revolução cultural. Rio de Janeiro: Civilização Brasileira, 1968.

LÊNIN, V. I. Sobre a educação. Lisboa: Seara Nova, 1977 (Volume I e II).

LENIN, V. I. Materialismo e Empiriocriticismo. Moscou: Edições Progresso. Portugal: Edições Avante, 1983.

LENIN, V. I. O esquerdismo: doença infantil do comunismo. São Paulo: Expressão Popular, 2014.

MALLY, L. The Proletkult Movment in revolutionary Russia. Berkley: University of California Press, 1990.

SOCHOR, Z. Revolution and culture: the Bogdanov-Lenin controversy. London: Cornel University Press, 1988.

TROTSKI, L. História da revolução Russa. Rio De janeiro: Editora Saga, 1967

TROTSKI, L. Literatura e Revolução. Rio de Janeiro: Zahar - Jorge Zahar Editor, 2007.

TROTSKI, L. A Revolução Permanente. São Paulo: Expressão Popular, 2007a.

\section{Notas}

' O comunismo de guerra foi "uma política resultante das condições de guerra e caracterizou-se pela extrema centralização da produção e da distribuição de artigos, pela proibição do comércio livre e pelo sistema de desapropriação de viveres, segundo o qual os camponeses eram obrigados a entregar ao Estado todo o excedente de produtos agropecuários (Nota do tradutor, In Lenini, 1968, p. 134).

i O termo "Machismo" é em alusão ao principal elaborador do empiriocriticismo, Ernest Mach.

iii A Nova política Econômica, que admitiu por certo tempo a existência de elementos capitalistas num marco limitado ficando as posições econômicas fundamentais em mãos do Estado Proletário, teve por objetivo desenvolver as forças produtivas do país, elevar a economia agropecuária e criar a base econômica para a passagem ao socialismo. (Nota do tradutor. In: Lenin, 1969, p. 134).

iv Nesta época Lenin, por motivos de saúde, não conseguia manter o mesmo ritmo de trabalho e precisava ser substituído.

v Esses dois conceitos são distintos: "A ditadura do proletariado não é a organização econômica e cultural de uma sociedade, e sim o sistema revolucionário e militar que se propõe instaurá-la” (TROTSKI, 2007, p. 153).

${ }^{v i}$ Como já referido anteriormente, o Proletkult contava com mais de 400 mil membros no ano de 1918. Além disso, Lenin entendia que essa organização tinha concepções estranhas ao marxismo e que Bogdanov e seus companheiros e companheiras defendiam a total independência do movimento, colocando-se em oposição ao estado proletário. 
vii Com a morte de Lenin em 1924 e de Bogdanov em 1928, as ideias do movimento Cultura Proletária retomaram fôlego com Bukharin que integrava o governo Stalinista e passou a defender a teoria do realismo socialista.

viii Para ilustrar esta afirmação, a título de anúncio de estudos em desenvolvimento na pesquisa intitulada "memória e história das ideias e experiências educacionais e culturais contra-hegemônicas", chamo atenção às proposições da Educação Popular com destaque à pedagogia da libertação freireana, as pedagogias da prática, à pedagogia dos movimentos sociais que, em linhas gerais, reivindicam uma educação do povo, com o povo e para o povo como critério central para o desenvolvimento de suas lutas. Por sua vez, as formulações da Pedagogia Histórico-Crítica operam com o princípio geral de apropriação dos conhecimentos clássicos como critério para seleção e organização dos conteúdos escolares no sentido de máximo desenvolvimento das potencialidades humanas e suporte para melhor preparar os trabalhadores em suas lutas.

\section{Sobre o autor}

Cláudio Felix dos Santos. Licenciado em História (UPE), Mestre em educação (UFPE) e Doutor em educação (UFBA). Docente no Departamento de Filosofia e Ciências Humanas da Universidade Estadual do Sudoeste da Bahia, onde leciona nas licenciaturas e no programa de Pós-Graduação em Memória: Linguagem e sociedade. Coordenador do grupo de pesquisa Estudos marxistas em memória e história da educação, integrado ao Museu Pedagógico Padre Palmeira (UESB). Endereço Eletrônico: cefelix2@gmail.com 